\title{
Experimental and analytical study on flexural behaviour of concrete filled GFRP Box Beams
}

\author{
K.Vinayaki \\ Department of civil engineering \\ Mepco Schlenk Engineering college \\ Sivakasi - 626005
}

\author{
R.Theenathayalan \\ Department of civil engineering \\ Mepco Schlenk Engineering college \\ Sivakasi - 626005
}

\begin{abstract}
This paper deals with the experimental study on the variation in the load carrying capacity between concrete filled GFRP box beams of size $1200 \times 150 \times 200 \mathrm{~mm}$ is predicted by varying thickness of GFRP box beams as $4 \mathrm{~mm}, 6 \mathrm{~mm}$ and the concrete strength as M40. The material properties of cement, fine aggregate and coarse aggregate would be found out. The compressive strength of concrete cube would be found out to confirm the strength - grade 40. Study results showed that in addition to many advantages due to its formation, the Box Beam showed superior physical and mechanical properties. It was found that the flexural strength and fracture toughness values of Composite beams significantly increased stiffness when compared to reference values. Flexural two point load would be applied on the box beams filled with plain concrete. The experimental test was performed to find the flexural strength, load carrying capacity, deflection, load deflection relationship, load strain relationship and stiffness ratio for various thickness of box beams. The analytical Study was performed by using ANSYS to evaluate the deformation of the specimen. The experimental study of beams showed that the box beam having higher thickness will increase the load carrying capacity and stiffness and also decrease the deflection. In ANSYS by varying both thickness of GFRP box as well as grade of concrete is analysed. The proposed finite element model shows increased resistance to deformation when concrete is used as infill material and the deformation decreases when the grade of concrete and thickness of box beam increases.
\end{abstract}

Keywords: Glass Fiber Reinforced Polymer (GFRP), Box Beams, Flexural Strength, Stiffness.

\section{INTRODUCTION}

The needs and demands of humans in the field of material technologies increase each day in parallel to the problems experienced in materials. Researchers investigate new material types and applications and try to produce new designs to decrease these problems and to satisfy these demands .In recent years, many researchers have concentrated on composite materials, which can be considered as a derivative of these materials. Composite materials have required properties and are preferred in a wide variety of fields including the construction sector. In addition to their high resistance and good performance towards environmental factors, these materials are preferred since they have all the properties desired by the researchers and they can be produced in different combinations. In addition to their superior mechanical resistance, these new generation composite materials draw the attention of researchers due to the properties such as their lightweight structure, corrosion resistance and high resistance to chemicals, electric insulation, low density and high resistance/density ratio.

Concrete-filled glass fiber-reinforced polymer (GFRP) box beams represent an efficient structural building element having several advantages over conventional reinforced concrete elements. The GFRP Box acts as stay-inplace formwork, greatly reducing construction cost and time as well as serving as external reinforcement eliminating the need for internal steel reinforcement. In addition, the GFRP Box provides concrete confinement as well as increased resistance to degradation in corrosive environments. Although many studies have been performed for circular concrete-filled GFRP members in both axial and flexural applications, much less attention has been given to rectangular sections. The studies shows that a closed hollow rectangular GFRP section with webs extending above the compression flange providing formwork for a concrete compression flange. The investigated rectangular filament wound concrete filled tubes with combined axial and flexural loading, studied T-beams constructed of concrete filled rectangular GFRP pultruded beams with concrete slabs attached with shear studs.

GFRP composites are generally used in curtain wall systems, pedestrian and vehicle bridges, soil improvements, pipes, repair and reinforcement works in the construction industry. The construction sector constitutes a significant part of the GFRP composite market, followed by the automotive sector. However, since these materials are not yet well recognized by users and designers, they are not considered as a replacement for other materials. It is estimated that GFRP composites can be a good solution in a significant part of available applications. Recently, the use of composite materials has rapidly increased and it is gradually developing in many technical fields including the construction sector. In this development process, the construction industry is constantly working to develop new construction technology to design and obtain more economical solutions. These new generation composites, which are generally preferred in secondary constructions, which are not considered as bearing elements in the construction sector, are today also used as bearing elements, as main construction elements. Particularly after the increase of the serial production of GFRP composites, they began to be used more effectively in buildings for different purposes. The use of Glass fiber reinforced composites, which are lightweight and have a high resistance, in corrosion, repair and improvement works has increased.

Reinforcement and improvement works involving the wrapping of GFRP laminates on the bottom surfaces of beams and GFRP fabrics on all surfaces of columns are the most widely known applications of these types of composites with concrete. Like in various study units, the most recent 
research and development studies have concentrated on hybrid systems where conventional construction materials particularly such as concrete and composite materials are used in combination. Recently much of the research has focused on hybrid GFRP columns formed by concrete-filled or hollow GFRP pipes. The tendency in scientific studies clearly shows that in the near future, the use of GFRP composites in new buildings will mainly concentrate on the use of box structure. Many studies have shown that the use of GFRP composites with conventional materials like concrete were one of the solutions to eliminate certain deficiencies and disadvantages in construction elements. The first studies on hybrid designs, where GFRP profiles and concrete were used in combination, began. In the first studies, positive results were obtained by using concrete to increase rigidity and compressive strength inside GFRP profile.

The idea of using GFRP - Concrete box system as a flexural element it were reported that the GFRP profile used in the formed system offered advantages in formwork, lightweight structure and resistance and could yield more than50\% lightweight structure when compared to conventional plate systems. They formed permanent formwork by using concrete in a T-section GFRP profile and increased material resistance. In previous studies on hybrid systems which were formed by filling concrete inside the GFRP profile; the behavior of a box beam system under uniaxial load flexural behavior were again analyzed. Various studies were conducted on the long term creep and shrinkage effects of box beams, on behaviors under repetitive loads, on the effects on impact loads, on shear behavior and material fatigue and on frost-thaw effects.

\section{MATERIAL USED}

Cement: Ordinary Portland cement of 53 grade confirming to IS $8112-1989$ and specific gravity of 3.15 is used.

\begin{tabular}{|c|c|c|}
\hline Sl.No & Tests & Results \\
\hline 1 & Specific gravity & 3.15 \\
\hline 2 & Initial setting time & 80 minutes \\
\hline 3 & Final setting time & 453 minutes \\
\hline 4 & $\begin{array}{c}\text { 28days compressive } \\
\text { strength }\end{array}$ & $45.33 / \mathrm{mm}^{2}$ \\
\hline
\end{tabular}

Table 1 Properties of cement

Fine aggregate: Locally available Natural River sand of specific gravity 2.6 and size below $4.75 \mathrm{~mm}$ confirming to zone II of IS $383-1970$ is used. Its fineness modulus and bulk density are 2.67 and $1415 \mathrm{~kg} / \mathrm{m}^{3}$

\begin{tabular}{|c|c|c|}
\hline $\begin{array}{c}\text { Sl.N } \\
0\end{array}$ & Tests & Results \\
\hline 1 & Specific gravity & 2.67 \\
\hline 2 & Fineness modulus & 2.67 \\
\hline 3 & Water absorption & $0.6 \%$ \\
\hline
\end{tabular}

Table 2 Properties of fine aggregate

Coarse aggregate: Crushed stone of size less than $20 \mathrm{~mm}$ with specific gravity of 2.66 and bulk density of $1415 \mathrm{~kg} / \mathrm{m}^{3}$ is used

\begin{tabular}{|c|c|c|}
\hline $\begin{array}{c}\text { S1.N } \\
0\end{array}$ & Tests & Results \\
\hline 1 & Specific gravity & 2.72 \\
\hline 2 & Fineness modulus & 2.67 \\
\hline 3 & Bulk density & $1806 \mathrm{~kg} / \mathrm{m}^{3}$ \\
\hline 4 & Water absorption & $1.1 \%$ \\
\hline
\end{tabular}

Table 3 Properties of coarse aggregate

Super plasticizer : Conplast SP 430 is based on sulphonated Naphthalene Polymer and supplied as brown liquid instantly dispersible in water, having specific gravity of 1.220 to 1.225 @ $30^{\circ} \mathrm{C}$

\section{PROPORTION}

Design of concrete mixes involves determination of the proportions of the given constituents namely, cement, Water, Coarse aggregate and fine aggregate with admixtures if any. Workability is specified as the important property of concrete in the fresh state. For hardened state compressive strength and durability will be considered. According to IS $1343-2009$ mix ratio for M40 grade is $1: 2.56: 3.26: 0.4$

\section{GFRP BOX}

In this paper GFRP BOX of various thickness such as $4 \mathrm{~mm}$ and $6 \mathrm{~mm}$ is used for concrete filling. The GFRP BOX acts as stay in-place formwork, greatly reducing construction cost and time as well as serving as external reinforcement eliminating the need for internal steel reinforcement. GFRP BOX provides concrete confinement as well as increased resistance to degradation in corrosive environments. The boxbeams made of the fiber-reinforced composite materials are used extensively in many engineering applications because of their good mechanical properties, such as high strength.

\begin{tabular}{|l|c|}
\hline Density, $\mathrm{Kg} / \mathrm{m}^{3}$ & 1960 \\
\hline $\mathrm{E}_{\mathrm{a}} \mathrm{Gpa}$ & 505 \\
\hline $\mathrm{E}_{\mathrm{b}} \mathrm{Gpa}$ & 9.9 \\
\hline $\mathrm{Pr}_{\mathrm{ba}}$ & 0.063 \\
\hline $\mathrm{G}_{\mathrm{ab}} \mathrm{Gpa}$ & 3.7 \\
\hline $\mathrm{G}_{\mathrm{bc}} \mathrm{Gpa}$ & 1.4 \\
\hline $\mathrm{G}_{\mathrm{ca}} \mathrm{Gpa}$ & 1.4 \\
\hline $\mathrm{X}_{\mathrm{c},} \mathrm{Gpa}$ & 2.277 \\
\hline $\mathrm{X}_{\mathrm{t}}$ Gpa & 1.265 \\
\hline $\mathrm{Y}_{\mathrm{c}, \mathrm{Gpa}}$ & 0.065 \\
\hline $\mathrm{Y}_{\mathrm{t}}, \mathrm{Gpa}$ & 0.05 \\
\hline
\end{tabular}

Table 4 Material properties of GFRP 


\section{SPECIMEN DETAILS}

A box beam of length $1200 \mathrm{~mm}$ and width $150 \mathrm{~mm}$ having depth $200 \mathrm{~mm}$ is casted for varying thickness of GFRP Box as $4 \mathrm{~mm}$ and $6 \mathrm{~mm}$ respectively. The concrete of grade M40 is filled inside the box beam. The Box itself acts as a external reinforcement so there is no need for any internal reinforcement. Four specimens are casted for various thickness.

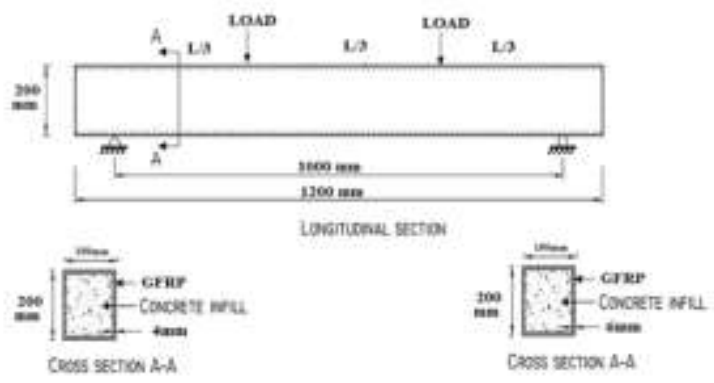

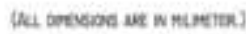

Fig 1 Beam specification details

\section{EXPERIMENTAL STUDY}

The beam were simply supported over an effective span of $1000 \mathrm{~mm}$ and the loads were applied vertically as two point static loading , at the middle third position of the beam, vertical displacement and strains were monitored throughout the test. The displacements were measured at mid-span using LVDT and strain was measured by a DEMEC (detachable mechanical gauge) with gauge points. The beams were loaded using hydraulic jack. The load was measured by means of load cell. The load was applied at an increment of $10 \mathrm{KN}$, for each load interval the deflections were measured. The 50T capacity testing frame was used for testing of beams.

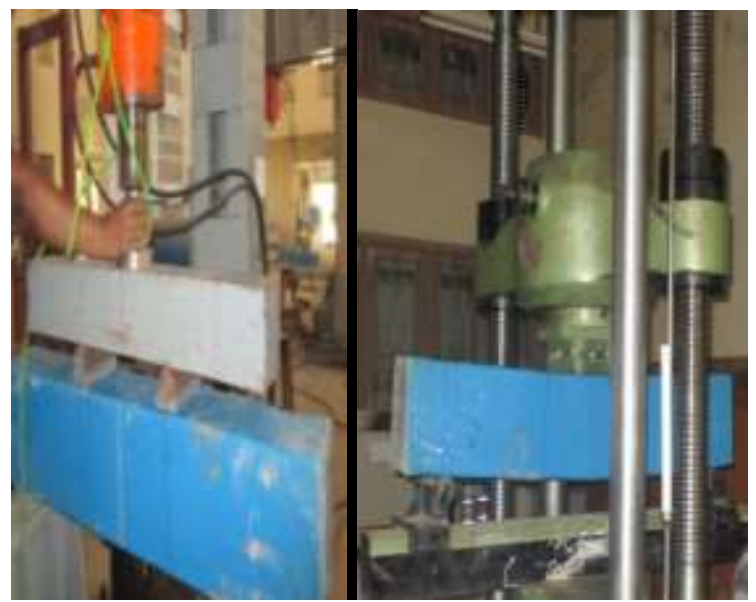

FIG 2 EXPERIMENTAL TEST SETUP

\section{EXPERIMENTAL TEST RESULT}

The following are the result obtained during experiment. The result are as follows :

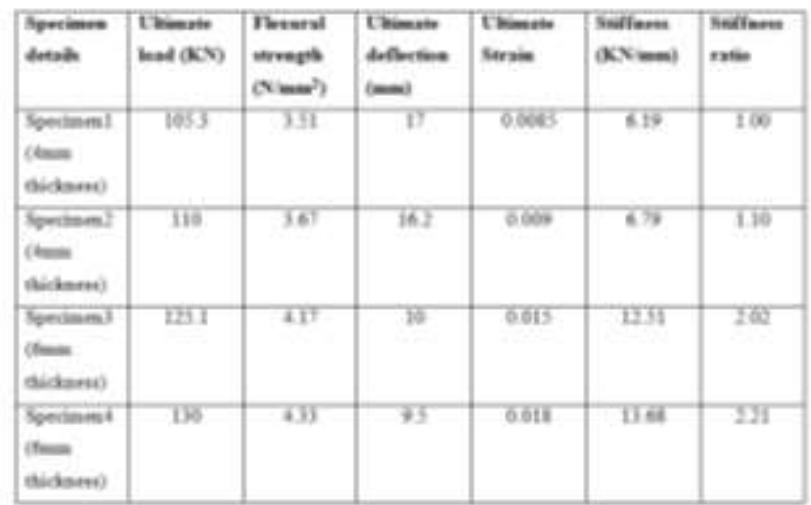

Table 5 Test results

Load-Deflection relationship

The deformation and load carrying capacity of GFRP box for

Fig 3 Load Vs Deflection curve

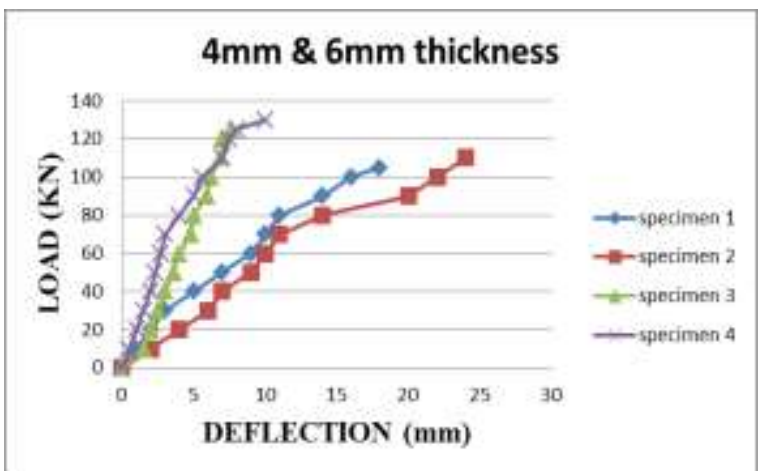

various thickness is found experimentally. The load carrying capacity increases with increase in thickness of GFRP box and the deflection gets decreases with increase in thickness. So the deflection level considerably less for higher thickness and the load carrying capacity will be higher for increased thickness.

\section{LOAD -STRAIN BEHAVIOUR}

Fig 4 compares the load - strain relationships for various beam specimen. It is seen that the GFRP box having higher thickness withstand more strain compared to box beam having minimum thickness with increasing load.

Fig 4 Load vs Strain Curve

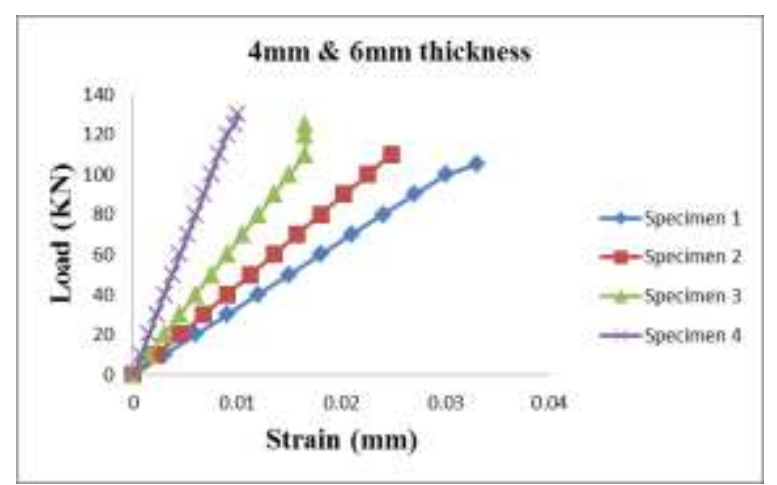




\section{LOAD - STIFFNESS RELATIONSHIP}

As the thickness increases the stiffness also increases. The specimen 4 showed high stiffness compared to specimen 1

Fig 5 Load vs Stiffness curve

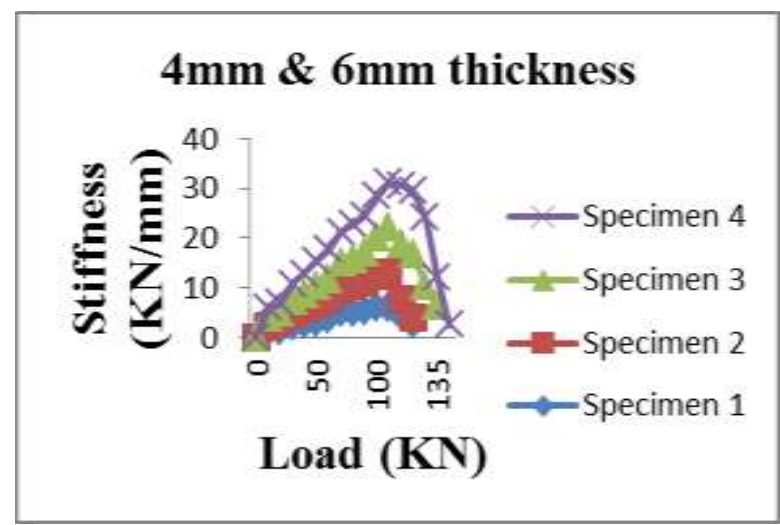

Fig 6 STIFFNESS RATIO

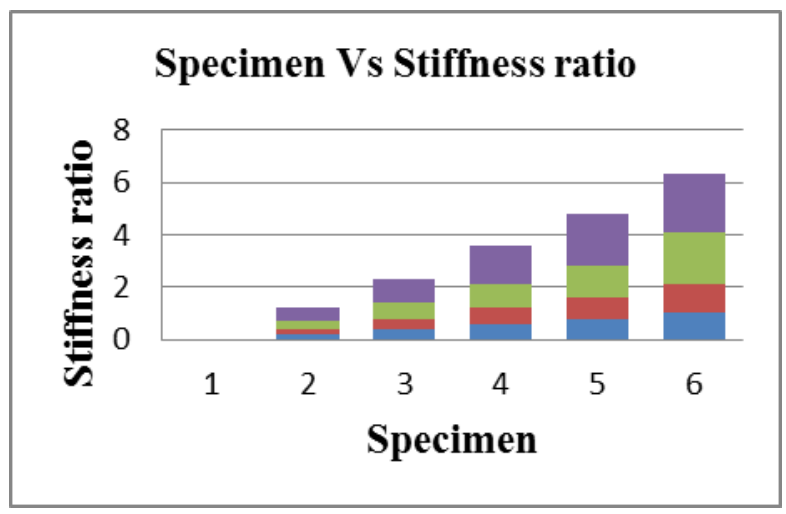

\section{FAILURE PATTERN}

Fig 7 Deformed Shape of box beam

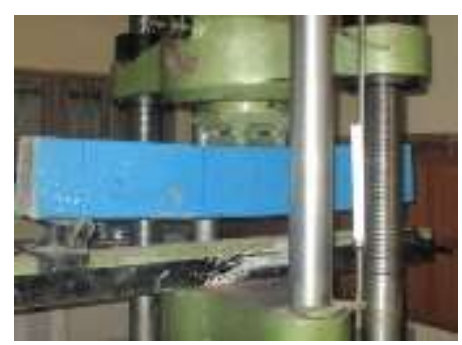

Fig 8 Crushed infilled concrete at ultimate load

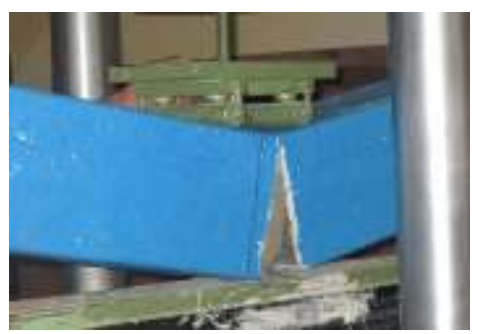

\section{ANALYTICAL STUDY}

ANSYS is a general purpose finite element analysis (FEA) Software Package. Finite element analysis is a numerical method of deconstructing a complex system into very small pieces (of user-designated size) called elements. The software implements equations that govern the behavior of these elements and solves them all; creating a comprehensive explanation of how the system acts as a whole. These results then can be presented in tabulated or graphical forms. This type of analysis is typically used for the design and optimization of a system far too complex to analyze by hand. Systems that may fit into this category are too complex due to their geometry, scale or governing equations.

\section{FINITE ELEMENT MODELLING}

The ultimate purpose of this finite element modelling is to recreate mathematically the behaviour of structures and components. It is also used for obtaining the deflections occurred in any structure under any loading conditions. The results obtained can then be compared with the Experimental values.

\section{PRE-PROCESSING}

Define the element type, Real constants, Material models of the concrete model.

\section{Element type}

SOLID 65 allows the presence of four different materials within each element, one matrix material (e.g concrete).Concrete material is capable of directional integration point cracking and crushing besides incorporating plastic and creep behaviour. Shell 181 is used for concrete filled box beam. Concrete material is assumed to be initially isotropic. GFRP material having orthotropic nature. Element is defined by eight nodes having three degrees of freedom at each node: translations in the nodal $\mathrm{x}-, \mathrm{y}-$,and $\mathrm{z}$ - directions. Special features of SOLID 65 are : Plasticity, Creep, Cracking, Crushing, Large deflection and Large Strain.

\section{Real constants}

Real Constant Set 1 is used for the Solid 65 element. Real constant set 2 is used for the shell element for that the thickness of box such as $3 \mathrm{~mm}, 4 \mathrm{~mm}, 5 \mathrm{~mm}$ and $6 \mathrm{~mm}$.

\section{Material model}

Two material models were given : material 1 for concrete and material 2 for box element, under linear isotropic and orthotropic material definition.

Table 6 Details of specimen

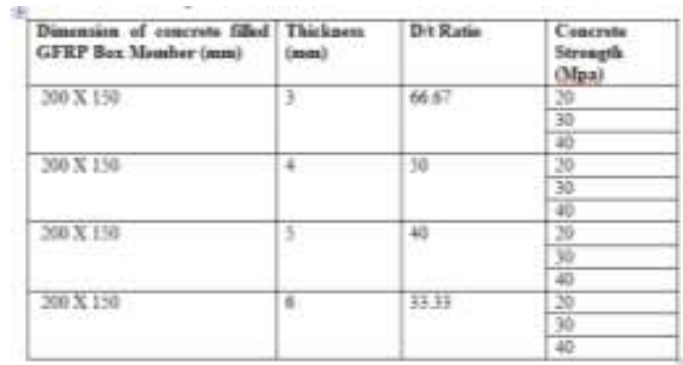

Modelling

The model was created using key points, lines. Then it is extruded to get the volume. The length of the beam is taken as $1200 \mathrm{~mm}$. No additional reinforcement is used in the sections. 


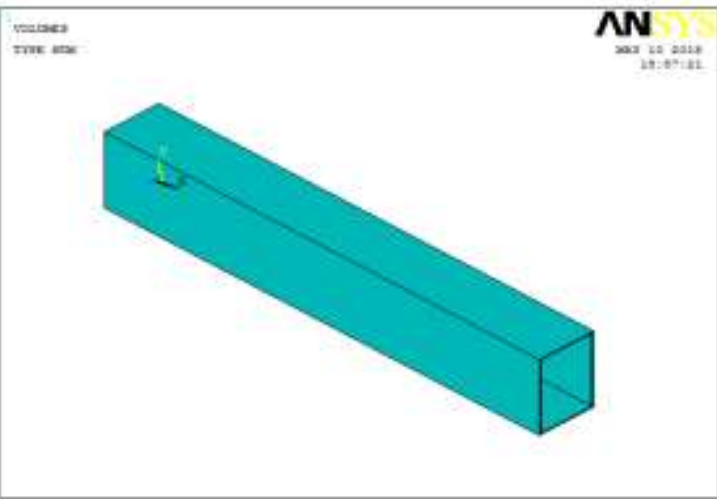

g 9 Box Beam mode

\section{Meshing}

For Solid 65 element the mesh was set up such that square or rectangular elements were created. The beam was meshed by both line and volume mesh.

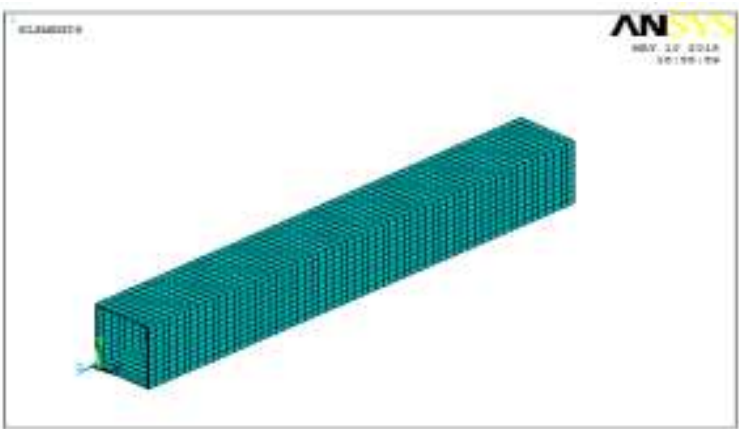

Fig 10 Box Beam after meshing

\section{Boundary conditions and loads}

Displacement boundary conditions are needed to constrain the model to get a unique solution .To ensure that the model acts the same way as the experimental beam, boundary conditions need to be applied at points of symmetry and where the supports and loadings exist.

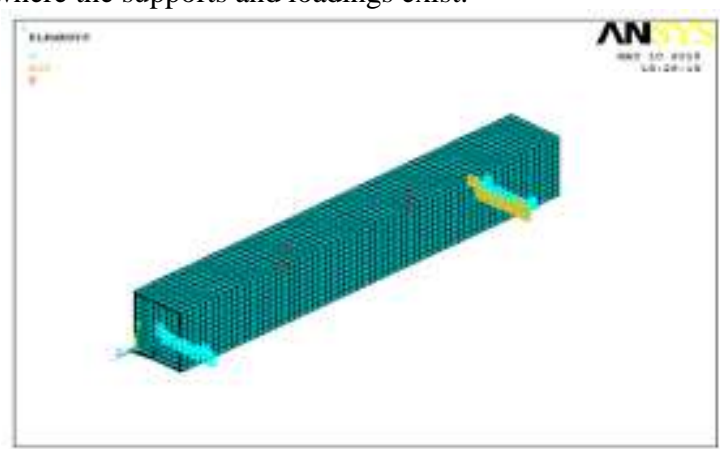

Fig 11 Two point loading acting in Beam

\section{Post - Processing}

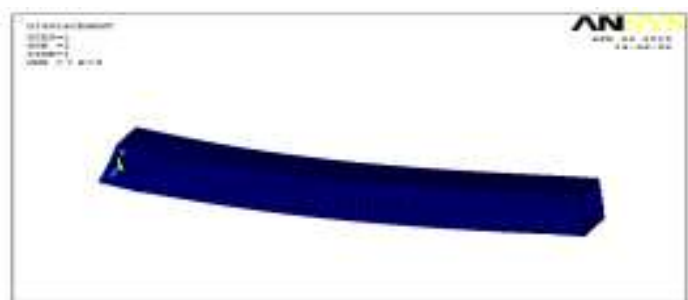

Fig 13 Deformed + Undeformed Solution

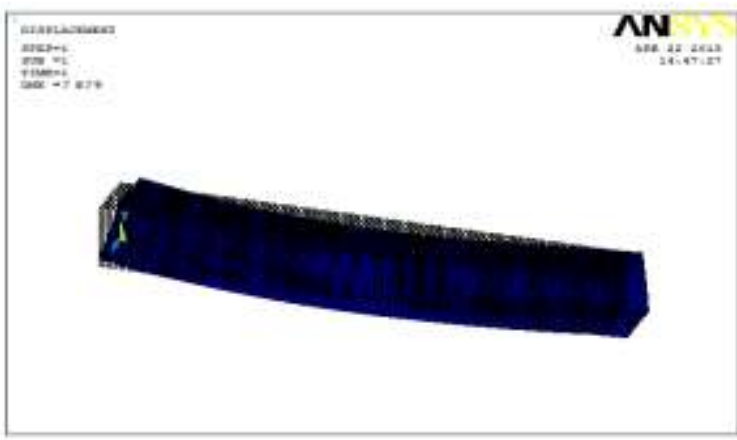

Fig 14 Nodal Solution

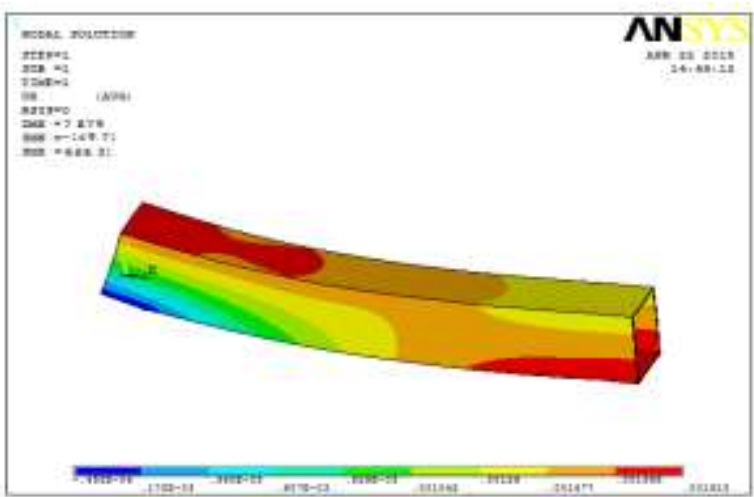

Fig 15 Vector Solution

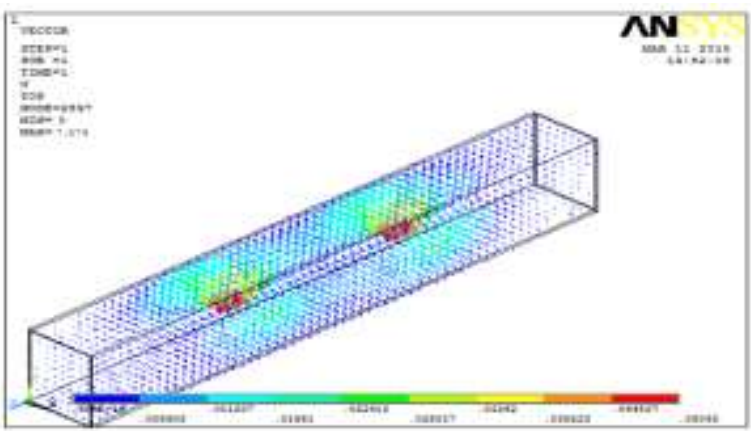

Fig 16 Von Mises Stresses

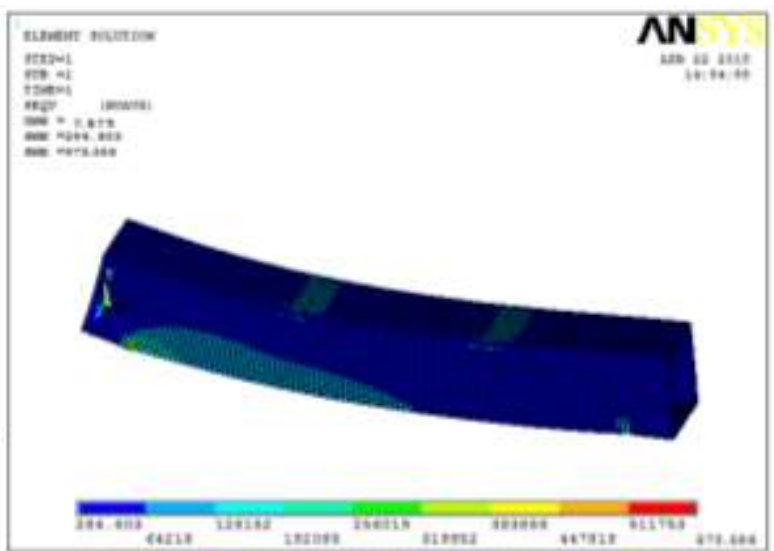

Fig 12 Displacement of beam 
Fig 17 Nodal Solution of the beam

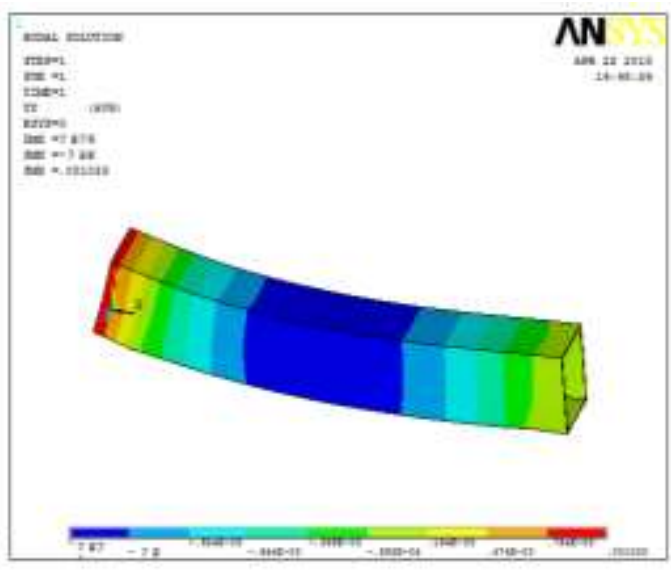

Fig 18 Element Solution of the beam

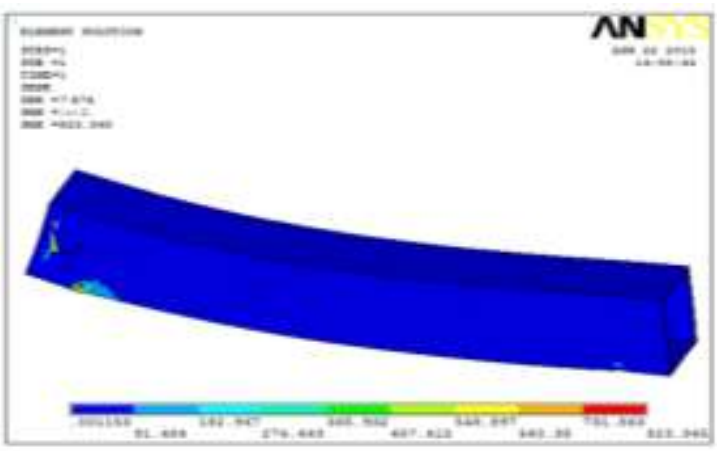

Fig 19 Shear stress of the beam

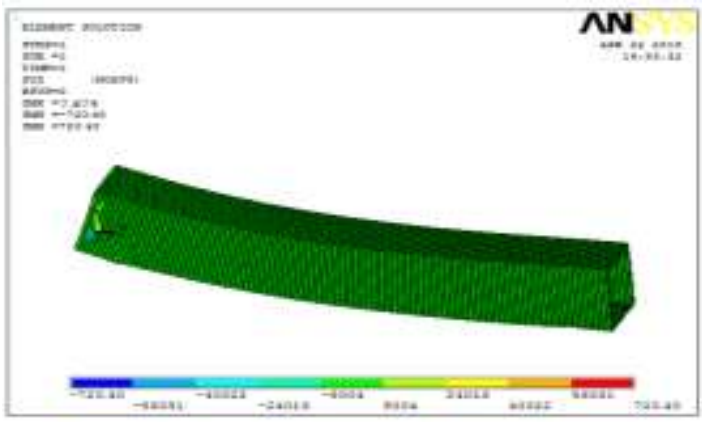

Fig 20 Cracks \& Crushing

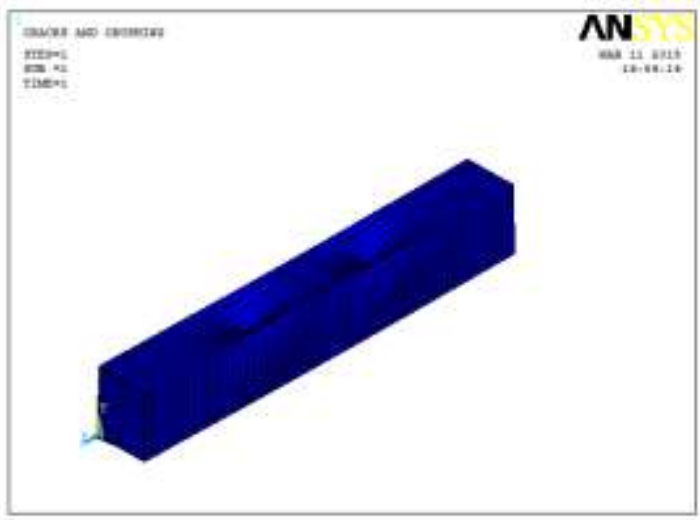

\section{RESULTS \& DISCUSSION}

The load versus deflection behavior of typical concrete filled GFRP Box beam sections is given in Figures 21 and 22 ,respectively. It can be seen that the total deformation at any given load for all concrete filled sections is lesser because of the increase in stiffness due to the infill. In all cases as the grade of concrete increases, more improved performance against deformation is seen. The deformation capacity of the analyzed specimens was significantly plotted. The load carrying capacity of the specimen having increased grade having increased thickness is significantly increased. The deflection is higher for beam having minimum thickness similarly beam with high grade will having minimum deflection level than beam having less grade of concrete will deflect more.

Fig 21 Load Vs Deflection Curve For 3mm thickness

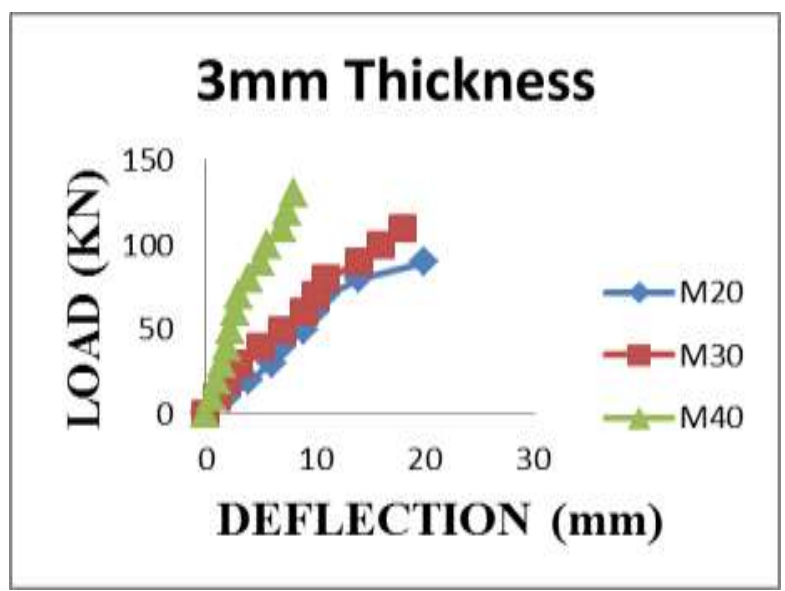

Fig 22 Load Vs Deflection Curve For 4mm thickness

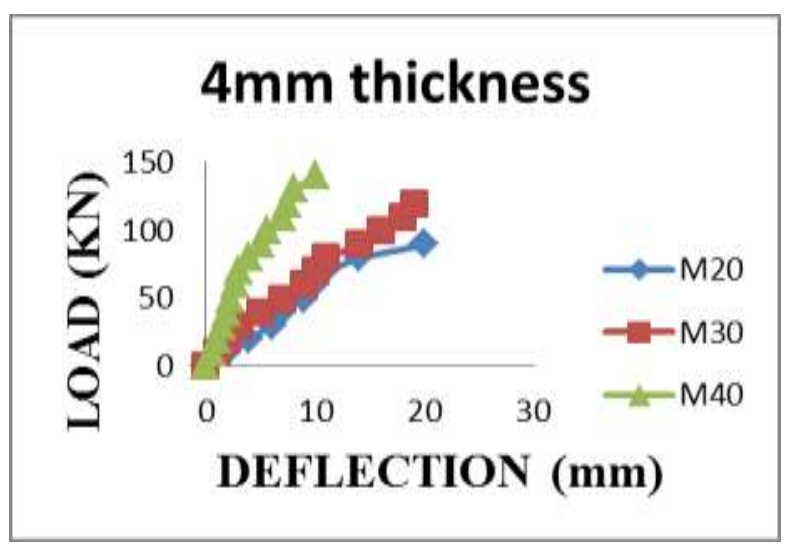

Fig 23 Load Vs Deflection Curve For $5 \mathrm{~mm}$ Thickness 


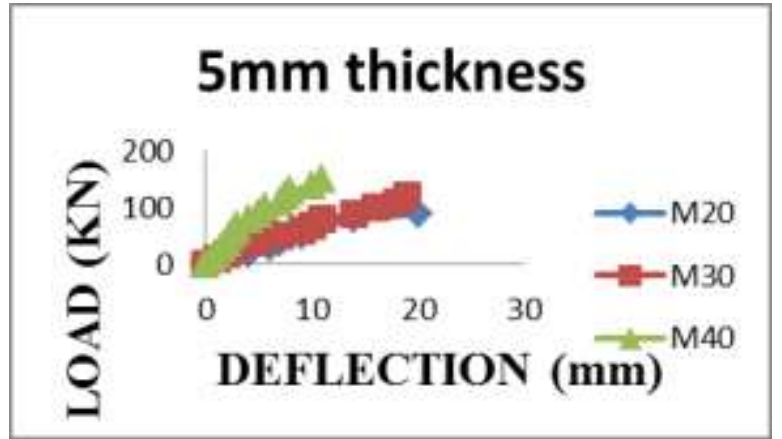

Fig 24 Load Vs Deflection Curve For 6mm Thickness

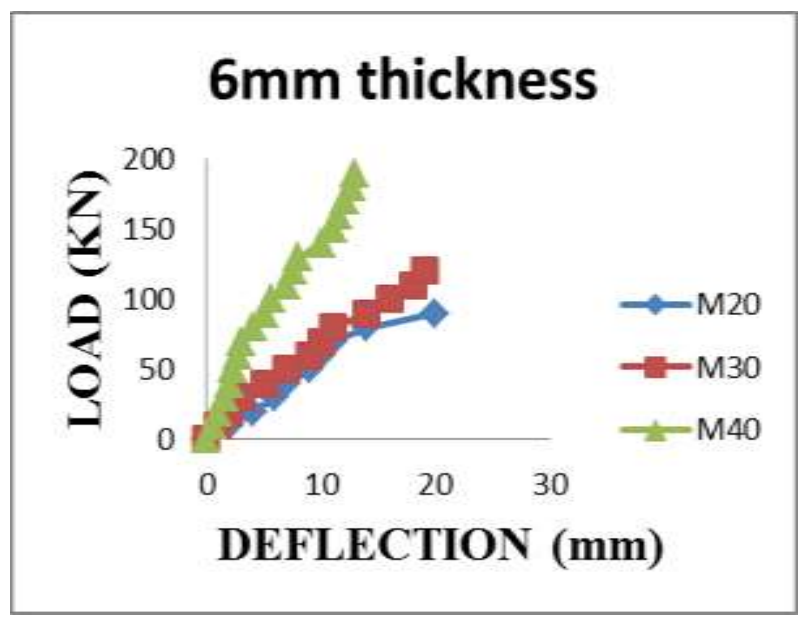

Fig 25 Maximum Deformation of beams

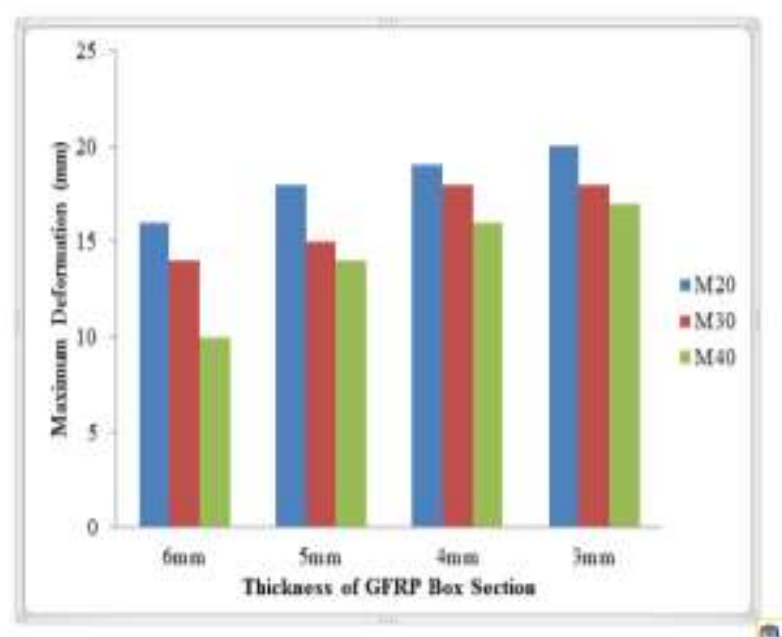

The load versus total deformation capacity of the concrete filled GFRP box beam sections for different thickness is shown in Figure 21,22,23 \& 24.It can be seen that concrete filled box beam exhibit less deformation irrespective of the thickness. It is also observed that the deformation decreases when the grade of infill increases. The stiffness of the concrete filled GFRP box is nearly 4 to 7.5 times of conventional beam. From the Figure 25 it is observed that the deformation of beam with $6 \mathrm{~mm}$ thickness shows higher resistance to deformation than other beams. The reduction in deflection of $6 \mathrm{~mm}$ thick concrete filled GFRP box section is about $58 \%$ when compared to conventional beam.

\section{CONCLUSION}

Based on the experimental and analytical study, following conclusions were made:

The proposed finite element model shows the resistance to deformation when concrete is used as infill material and the deformation decreases when the grade of concrete and thickness of box beam increases. The Concrete filled GFRP box beam with $6 \mathrm{~mm}$ thickness shows good response against deformation. The load carrying capacity of box beam is increased 3 times when compared to normal conventional concrete. Increasing the grade of concrete will increase the moment carrying capacity as well as having increased stiffness up to $70 \%$. The stiffness of the concrete filled GFRP box is nearly 4 to 7.5 times of conventional beam. The beam having $6 \mathrm{~mm}$ thickness showed higher stiffness ratio of $2.21 \%$.The reduction in deflection of $6 \mathrm{~mm}$ thick concrete filled GFRP box section is about 58\% when compared to conventional beam. Deflections and stresses at the two point of the beam along with initial and progressive cracking of the finite element model compare well to experimental data obtained from concrete filled GFRP box beams.The failure mechanism of Concrete filled GFRP box beam is modelled quite well using FEA, and the failure load is very close to the failure load measured during experimental testing.

\section{ACKNOWLEDGEMENT}

I sincerely express my deepest sense of my thanks and gratitude to my guide for his valuable suggestions, excellent guidance and constant support I would like to express my gratitude and sincere thanks to our Head of the Department for providing all the facilities. I thank teaching and non teaching staff members of Civil Engineering Department, all my friends and parents who give constant support and encouragement

\section{REFERENCES}

1. FerhatAydın, MehmetSarıbıyı, "Investigation of flexural behaviors of hybrid beams formed with GFRP box section and concrete" Journal of Construction and Building Materials 41 (2013) 563-569

2. B. E. Belzer, M. J. Robinson, D. R. Fick, "Composite Action of Concrete -Filled Rectangular GFRP Tubes" Journal of Composites for Construction 32 (2013) 175 - 189

3. Huu-Tai Thai a, Brian Uya, Mahbub Khana, Zhong Tao, Fidelis Mashiri, "Numerical modelling of concrete-filled steel box columns incorporating high strength materials" Journal of Constructional Steel Research 102 (2014) 256-265

4. Bishnu Prasad Gautam and Takashi Matsumoto, "Shear deformation and interface behaviour of concrete-filled CFRP box beams" Journal of Composite Structures 89 (2009) 20-27

5. Kyungsik Kima, Chai H. Yoob, "Ultimate strengths of steel rectangular box beams subjected to combined action of bending and torsion" Journal of Engineering Structures 30 (2008) 1677-1687 
6. Thuc Phuong Vo, Jaehong Lee, "Flexural-torsional behavior of thin-walled closed-section composite box beams" Journal of Engineering Structures 29 (2007) 17741782

7. B. Uy, "Strength of short concrete filled high strength steel box columns" Journal of Constructional Steel Research 57 (2001) 113-134

8. Thuc Phuong Vo, Jaehong Lee, "Interaction curves for vibration and buckling of thin-walled composite box beams under axial loads and end moments" Journal of Applied Mathematical Modelling 34 (2010) 3142-3157

9. Bishnu Prasad Gautam and Takashi Matsumoto, "Failure Mechanism of Empty and Concrete-Filled CFRP Box Beams" Journal of Composite material and Construction 14 (2010) 336-345

10. Yunita Idris and Togay Ozbakkaloglu, "Seismic Behavior of High-Strength Concrete-Filled FRP Tube Columns" Journal of Composite material and Construction 17 (2013) 183-196

11. M. Gokhan Gunay and Taner Timarci, "Free Vibration of Composite Box-beams by ANSYS", Journal of Constructional Steel Research 60 (2004) 313-337

12. Arivalagan.S, Kandasamy.S, "Flexural and Cyclic Behaviour of Hollow and Concrete- Filled Steel Tubes" Journal of Constructional Steel Research 60 (2004) 313-337

13. Wassim Naguib and Amir Mirmiran, "Flexural Creep Tests and Modeling of Concrete-Filled Fiber Reinforced Polymer Tubes" Journal of composite material and Construction 6 (2002) 272-279

14. Bishnu Prasad Gautam, "Damage and failure mechanism of concrete filled CFRP box beams" Journal of Structural Engineer 38 (2008) 356-369
15. Libo Yan , Nawawi Chouw, "Experimental study of flax FRP tube encased coir fibre reinforced concrete composite column" Journal of Construction and Building Materials 40 (2013) 1118-1127 